\title{
TWENTY-FIFTH ANNUAL LIST OF PAPERS
}

\section{READ BEFORE THE AMERICAN MATHEMATICAL SOCIETY AND SUBSEQUENTLY PUBLISHED, INCLUDING REFERENCES TO THE PLACES OF THEIR PUBLICATION.}

Alexander, J. W., II. Functions which map the interior of the unit circle upon simple regions. Read April 24, 1915. Annals of Mathematics, ser. 2, vol. 17, No. 1, pp. 12-22; Sept., 1915.

Altshiller, N. On the circles of Apollonius. Read Aug. 3, 1915 . American Mathematical Monthly, vol. 22, No. 8, pp. 261-263; Oct., 1915: No. 9, pp. 304-305; Nov., 1915.

Barrow, D. F. Oriented circles in space. Read Jan. 2, 1915. Transactions of the American Mathematical Sociely, vol. 16, No. 3, pp. 235258; July, 1915.

BATEMAN, H. A certain system of linear partial differential equations. Read Feb. 26, 1916. Bulletin of the American Mathematical Society, vol. 22, No. 7, pp. 329-335; April, 1916.

BeEtLe, R. D. On the complete independence of Schimmack's postulates for the arithmetic mean. Read April 25, 1914. Mathematische Annalen, vol. 76, No. 4, pp. 444-446; June, 1915.

- Congruences associated with a one-parameter family of curves. Read Dec. 31, 1913 and Sept. 8, 1914. American Journal of Mathematics, vol. 37, No. 3, pp. 281-308; July, 1915.

Bennetw, A. A. The iteration of functions of one variable. Read Aug. 4, 1915. Annals of Mathematics, ser. 2, vol. 17, No. 1, pp. 23-60; Sept. 1915.

Bernstein, B. A. A set of four independent postulates for Boolean algebras. Read Aug. 3, 1915. Transactions of the American Mathematical Society, vol. 17, No. 1, pp. 50-52; Jan., 1916.

- A simplification of the Whitehead-Huntington set of postulates for Boolean algebras. Read (San Francisco) Nov. 20, 1915. Bulletin of the American Mathematical Society, vol. 22, No. 9, pp. 458-459; June, 1916.

BırкноFғ, G. D. The restricted problem of three bodies. Read Dec. 30 , 1913 and April 25, 1914. Rendiconti del Circolo Matematico di Palermo, vol. 39, No. 3, pp. 265-334; May-June, 1915.

- Theorem concerning the singular points of ordinary linear differential equations. Read Oct. 30, 1915. Proceedings of the National Academy of Sciences, vol. 1, No. 12, pp. 578-581; Dec., 1915.

Busss, G. A. A note on the problem of Lagrange in the calculus of variations. Read Dec. 31, 1915. Bulletin of the American Mathematical Society, vol. 22, No. 5, pp. 220-225; Feb., 1916.

Jacobi's condition for problems of the calculus of variations in parametric form. Read (Chicago) April 2, 1915. Transactions of the American Mathematical Society, vol. 17, No. 2, pp. 195-206; April, 1916. 
Blumberg, $H$. On the factorization of various types of expressions. Read (Southwestern Section) Nov, 28, 1914 and (Chicago) Dec. 29, 1914. Proceedings of the National Academy of Sciences, vol. 1, No. 6, pp. 374-381; June, 1915.

Buchanan, D. Oscillations near one of the isosceles-triangle solutions of the three body problem. Read Jan. 1, 1913. Proceedings of the London Mathematical Society, ser. 2, vol. 14, No. 4, pp. 278-300; July, 1915.

- A new isosceles-triangle solution of the three body problem. Read (Chicago) Dec. 28, 1914. Transactions of the American Mathematical Society, vol. 16, No. 3, pp. 259-274; July, 1915.

CAJORI, F. The history of Zeno's arguments on motion: phases in the development of the theory of limits. Read Sept. 9, 1913 and (Chicago) April 11, 1914. American Mathematical Monthly, vol. 22, No. 5, pp. 143-149; May, 1915: No. 6, pp. 179-186; June, 1915: No. 7, pp. 215220; Sept., 1915: No. 8, pp. 253-258; Oct., 1915: No. 9, pp. 292-297; Nov., 1915.

Carmichaed, R. D. On the representation of numbers in the form $x^{3}+y^{3}$ $+z^{3}-3 x y z$. Read Aug. 3, 1915. Bulletin of the American Mathematical Society, vol. 22, No. 3, pp. 111-117; Dec., 1915.

- Diophantine analysis (Mathematical Monograph Series, No. 16); pp. 35-58, 62-66, 77-84, 104-111. Read (Chicago), April 3, 1915. New York, Wiley, 1915.

- On the solutions of linear homogeneous difference equations. Read (Chicago) April 3, 1915. American Journal of Mathematics, vol. 38, No. 2, pp. 185-220; April, 1916.

Carpenter, A. F. Ruled surfaces whose flecnode curves have plane branches. Read (Chicago) Dec. 28, 1914. Transactions of the American Mathematical Society, vol. 16, No. 4, pp. 509-532; Oct., 1915.

Coвle, A. B. An isomorphism between theta characteristics and the $(2 p+2)$-point. Read Jan. 1, 1915. Annals of Mathematics, ser. 2, vol. 17, No. 3, pp. 101-112; March, 1916.

Cummings, L. D., and White, H. S. Groupless triad systems on fifteen elements. Read April 24, 1915. Bulletin of the American Mathematical Society, vol. 22, No. 1, pp. 12-16; Oct., 1915.

Curtiss, D. R. Extensions of Descartes' rule of signs connected with a problem suggested by Laguerre. Read Jan. 1, 1913 and (Chicago) Dec. 26, 1913. Transactions of the American Mathematical Society, vol. 16, No. 3, pp. 350-360; July, 1915.

Daniell, P. J. The coefficient of end-correction. Read (Southwestern Section) Nov. 28, 1914. Philosophical Magazine, ser. 6, vol. 30, No. 175, pp. 137-146; July, 1915: No. 176, pp. 248-256; Aug., 1915.

Dickson, L. E. Geometrical and invariantive theory of quartic curves modulo 2. Read (Chicago) April 2, 1915. American Journal of Mathematics, vol. 37, No. 4, pp. 337-354; Oct., 1915.

- Invariantive classification of pairs of conics modulo 2. Read Aug. 3, 1915. American Journal of Mathematics, vol. 37, No. 4, pp. 355-358; Oct., 1915.

- On the twenty-eight bitangents to a quartic curve. Read (Chicago) April 11, 1914. Chapter 19 of Theory and applications of finite groups, by G. A. Miller, H. F. Blichfeldt and L. E. Dickson. New York, Wiley, 1916. 
Eisenhart, L. P. Conjugate systems with equal tangential invariants and the transformation of Moutard. Read Sept. 8, 1914. Rendiconti del Circolo Matematico di Palermo, vol. 39, No. 2, pp. 153-176; March-April, 1915.

- Surfaces $\Omega$ and their transformations. Read Jan. 1, 1915. Transactions of the American Mathematical Society, vol. 16, No. 3, pp. 275310; July, 1915.

- Surfaces with isothermal representation of their lines of curvature as envelopes of rolling. Read Oct. 30, 1915. Annals of Mathematics, vol. 17, No. 2, pp. 64-71; Dec., 1915.

- Transformations of surfaces $\Omega$ (second memoir). Read Dec. 28, 1915. Transactions of the American Mathematical Society, vol. 17, No. 1, pp. 53-99; Jan., 1916.

EмcH, A. A certain class of functions connected with Fuchsian groups. Read April 24, 1915. Bulletin of the American Mathematical Society, vol. 22, No. 1, pp. 33-37; Oct., 1915.

Epperson, C. A. Note on Green's theorem. Read April 24, 1915. Bulletin of the American Mathematical Society, vol. 22, No. 1, pp. 17-26; Oct., 1915.

Evans, G. C. The non-homogeneous differential equation of parabolic type. Read Sept. 8, 1914. American Journal of Mathematics, vol. 37, No. 4, pp. 431-438; Oct., 1915.

- Application of an equation in variable differences to integral equations. Read April 29, 1916. Bulletin of the American Mathematical Society, vol. 22, No. 10, pp. 493-503; July, 1916.

Ford, W. B. On the representation of arbitrary functions by definite integrals. Read (Chicago) April 3, 1915. Proceedings of the National Academy of Sciences, vol. 1, No. 7, pp. 431-435; July, 1915.

Fonsyth, C. H. A general formula for the valuation of bonds. Read (Chicago) Dec. 29, 1914. American Mathematical Monthly, vol. 22, No. 5, pp. 149-152; May, 1915.

- Osculatory interpolation formulas. Read Feb. 27, 1915. Quarterly Publications of the American Statistical Association, vol. 14, No. 110, pp. 583-589; June, 1915.

Fréchet, M. Sur les fonctionnelles bilinéaires. Read Feb. 27, 1915, Transactions of the American Mathematical Society, vol. 16, No. 3. pp. 215-234; July, 1915.

— On Pierpont's definition of integrals. Read Dec. 27, 1915. Bulletin of the American Mathematical Society, vol. 22, No. 6, pp. 295-298; March, 1916.

Frizeld, A. B. The permutations of the natural numbers can not be well ordered. Read Feb. 27, 1915. Bulletin of the American Mathematical Society, vol. 22, No. 2, pp. 71-73; Nov., 1915.

Gillespie, D. C. The Cauchy definition of a definite integral. Read Sept. 9, 1914. Annals of Mathematics, ser. 2, vol. 17, No. 2, pp. 61-63; Dec., 1915.

Green, G. M. Projective differential geometry of one-parameter families of space curves, and conjugate nets on a curved surface. Read Oct. 25, 1913. American Journal of Mathematics, vol. 37, No. 3, pp. 215246; July, 1915. 
On isothermally conjugate nets of space curves. Read Aug. 4, 1915. Proceedings of the National Academy of Sciences, vol. 1, No. 10, pp. 516-521; Oct., 1915.

- On the linear dependence of functions of several variables, and certain completely integrable systems of partial differential equations. Read Oct. 30, 1915. Proceedings of the National Academy of Sciences, vol. 2, No. 4, pp. 209-214; April, 1916.

Griffin, F. L. An experiment in correlating freshman mathematics. Read (San Francisco) May 22, 1914 . American Mathematical Monthly, vol. 22, No. 10, pp. 325-330; Dec., 1915.

Gronwall, T. H. A functional equation in the kinetic theory of gases. Read April 24, 1915. Annals of Mathematics, ser. 2, vol. 17, No. 1, pp. 1-4; Sept., 1915.

- Determination of all triply orthogonal systems containing a family of minimal surfaces. Read April 25, 1914. Annals of Mathematics, ser. 2, vol. 17, No. 2, pp. 76-100; Dec., 1915.

Sur une équation fonctionnelle dans la théorie cinétique des gaz. Read Feb. 26, 1916. Comptes Rendus de l'Académie des Sciences, vol. 162, No. 12, pp. 415-418; March 20, 1916.

Haskins, C. N. On the zeros of the function $P(x)$ complementary to the incomplete gamma function. Read Jan. 2, 1915. Transactions of the American Mathematical Society, vol. 16, No. 4, pp. 405-412; Oct., 1915.

- On the measurable bounds and the distribution of functional values of summable functions. Read Oct. 30, 1915. Transactions of the American Mathematical Society, vol. 17, No. 2, pp. 181-194; April, 1916.

H'Doubler, F. T. See Van Vleck, E. B.

Hoskins, L. M. Mass as quantity of matter. Read Aug. 4, 1915. Science, new ser., vol. 42, No. 1080, pp. 340-341; Sept. 10, 1915. "Quantity of matter" in dynamics. Read Aug. 4, 1915. American Mathematical Monthly, vol. 23, No. 2, pp. 34-41; Feb., 1916.

Irwin, F. A curious convergent series. Read (San Francisco) Nov. 20, 1915. American Mathematical Monthly, vol. 23, No. 5, pp. 149-152; May, 1916.

JACKson, D. A formula of trigonometric interpolation. Read Sept. 8, 1913. Rendiconti del Circolo Matematico di Palermo, vol. 39, No. 2, pp. 230-232; March-April, 1915.

- Expansion problems with irregular boundary conditions. Read Jan. 1, 1915. Proceedings of the American Academy of Arts and Sciences, vol. 51, No. 7, pp. 381-417; Nov., 1915.

- Note on rational functions of several complex variables. Read Feb. 28, 1914. Journal für die reine und angewandte Mathematik, vol. 146, No. 3, pp. 185-188; Jan., 1916.

Proof of a theorem of Haskins. Read Aug. 3, 1915. Transactions of the American Mathematical Society, vol. 17, No. 2, pp. 178-180; April, 1916.

- An elementary boundary value problem. Read April 29, 1916 . Bulletin of the American Mathematical Society, vol. 22, No. 8, pp. 393-397; May, 1916. 
KASNER, E. Conformal classification of analytic arcs or elements: Poincaré's local problem of conformal geometry. Read Oct. 25, 1913. Transactions of the American Mathematical Society, vol. 16, No. 3, pp. 333-349; July, 1915.

— Infinite groups generated by conformal transformations of period two (involutions and symmetries). Read Sept. 9, 1914 and Dec. 27, 1915. American Journal of Mathematics, vol. 38, No. 2, pp. 177-184; April, 1916.

KeLLOGG, O. D. The oscillation of functions of an orthogonal set. Read (Southwestern Section) Nov. 29, 1913. American Journal of Mathematics, vol. 38, No. 1, pp. 1-5; Jan., 1916.

KEYser, C. J. The human significance of mathematics. Read Aug. 3, 1915. Science, new ser., vol. 42, No. 1089, pp. 663-680; Nov. 12, 1915.

KIRCHER, E. Group properties of the residue classes of certain Kronecker modular systems and some related generalizations in number theory. Read (Chicago) April 10, 1914. Transactions of the American Mathematical Society, vol. 16, No. 4, pp. 413-434; Oct., 1915.

LAmond, J. K. The reduction of multiple $L$-integrals of separated functions to iterated $L$-integrals. Read Dec. 31, 1913. Transactions of the American Mathematical Society, vol. 16, No. 4, pp. 387-398; Oct., 1915.

LEFsChetz, S. On cubic surfaces and their nodes. Read (San Francisco) April 6, 1912. Kansas University Science Bulletin, vol, 9, No. 6, pp. 69-78; Dec., 1914.

Note on the $n$-dimensional cycles of an algebraic $n$-dimensional variety. Read (Southwestern Section) Nov. 27, 1915. Rendiconti del Circolo Matematico di Palermo, vol. 40, No. 1, pp. 38-43; July-Aug., 1915.

Linehan, P. H. Contributions to equilong geometry. Read Feb. 27, 1915. Author's Dissertation. Lancaster, 1915. 6+38 pp.

Love, C. E. On linear difference and differential equations. Read (Chicago) April 2, 1915. American Journal of Mathematics, vol. 38, No. 1, pp. 57-80; Jan., 1916.

LovitT, W. V. A type of singular points for a transformation of three variables. Read (Chicago) April 2, 1915. Transactions of the American Mathematical Society, vol. 16, No. 4, pp. 371-386; Oct., 1915.

- A type of singular points for a transformation of three variables. Read Dec. 31, 1915. Bulletin of the American Mathematical Society, vol. 22, No. 5, pp. 236-239; Feb., 1916.

MacMillaA, W. D. Convergence of the series $\sum_{i=0}^{\infty} \sum_{j=0}^{\infty} \frac{x^{i} y^{j}}{i-j \gamma}$ ( $\gamma$ irrational). Read (Chicago) April 3, 1915. Bulletin of the American Mathematical Society, vol. 22, No. 1, pp. 26-32; Oct., 1915.

Mason, T. E. Mechanical device for testing Mersenne numbers for primes. Read Sept. 9, 1914. Proceedings of the Indiana Academy of Science, 1914, pp. 429-431.

- On properties of the solutions of linear $q$-difference equations with entire function coefficients. Read (Chicago) April 11, 1914. American Journal of Mathematics, vol. 37, No. 4, pp. 439-444; Oct., 1915. 
MrLler, B. I. A new canonical form of the elliptic integral. Read Dec. 27, 1915. Proceedings of the National Academy of Sciences, vol. 1, No. 5, pp. 274-275; May, 1915.

Miller, G. A. Note on several theorems due to A. Capelli. Read Jan. 1, 1915. Giornale di Matematiche, vol. 53, Nos. 4-5, pp. 313-315; July-Oct., 1915.

- Independent generators of a group of finite order. Read (Chicago) April 3, 1915. Transactions of the American Mathematical Society, vol. 16, No. 4, pp. 399-404; Oct., 1915.

- Limits of the degree of transitivity of substitution groups. Read Aug. 3, 1915. Bulletin of the American Mathematical Society, vol. 22, No. 2, pp. 68-71; Nov., 1915.

- Upper limit of the degree of transitivity of a substitution group. Read Jan. 1, 1916. Proceedings of the National Academy of Sciences, vol. 2, No. 1, pp. 61-62; Jan., 1916.

Miser, W. I. On multiform solutions of linear differential equations having elliptic function coefficients. Read (Chicago) March 21, 1913. Transactions of the American Mathematical Society, vol. 17, No. 2, pp. 109-130; April, 1916.

Mitchell, H. H. On the generalized Jacobi-Kummer cyclotomic function. Read Dec. 28, 1915. Transactions of the American Mathematical Society, vol. 17, No. 2, pp. 165-177; April, 1916.

Moore, C. L. E. See Wilson, E. B.

Moore, R. L. On the linear continuum. Read April 24, 1915. Bulletin of the American Mathematical Society, vol. 22, No. 3, pp. 117-122; Dec., 1915.

- Concerning a non-metrical pseudo-Archimedean axiom. Read April 26, 1913. Bulletin of the American Mathematical Society, vol. 22, No. 5, pp. 225-236; Feb., 1916.

- On the foundations of plane analysis situs. Read April 24, 1915. Transactions of the American Mathematical Society, vol. 17, No. 2, pp. 131-164; April, 1916. Proceedings of the National Academy of Sciences, vol. 2, No. 5, pp. 270-272; May, 1916.

Moulton, E. J. On figures of equilibrium of a rotating compressible fluid mass; certain negative results. Read (Chicago) Dec. 27, 1913. Transactions of the American Mathematical Society, vol. 17, No. 1, pp. 100-108; Jan., 1916.

Nelson, A. L. Quasi-periodicity of asymptotic plane nets. Read (Chicago) April 21, 1916. Bulletin of the American Mathematical Society, vol. 22, No. 9, pp. 445-455; June, 1916.

OsGood, W. F. On functions of several complex variables. Read Oct. 30 , 1915. Transactions of the American Mathematical Society, vol. 17, No. 1, pp. 1-8; Jan., 1916.

- Note on functions of several complex variables. Read April 29, 1916. Bulletin of the American Mathematical Society, vol. 22, No. 9, pp. 443445; June, 1916.

PferfFer, G. A. On the conformal geometry of analytic arcs. Read Oct. 31, 1914. American Journal of Mathematics, vol. 37, No. 4, pp. 395-430; Oct., 1915. 
Poor, V. C. Transformation theorems in the theory of the linear vector function. Read Dec. 31, 1915. Bulletin of the American Mathematical Society, vol. 22, No. 4, pp. 174-181; Jan., 1916.

RANUm, A. Duality in the differential geometry of space-curves. Read Sept. 6, 1910. Quarterly Journal of Pure and Applied Mathematics, vol. 46, No. 4, pp. 356-384; Oct., 1915.

Richardson, I. J. Digital reckoning among the ancients. Read Aug. 3, 1915. American Mathematical Monthly, vol. 23, No. 1, pp. 7-13; Jan., 1916.

RItт, J. F. On certain real solutions of Babbage's functional equation. Read Feb. 27, 1915. Annals of Mathematics, ser. 2, vol. 17, No. 3, pp. 113-122; March, 1916.

Rowe, J. E. Relations among parameters along the rational cubic curve. Read April 24, 1915. Bulletin of the American Mathematical Society, vol. 22, No. 2, pp. 74-76; Nov., 1915.

- A new method of finding the equation of a rational plane curve from its parametric equations. Read Dec. 27, 1915. Bulletin of the American Mathematical Society, vol. 22, No. 7, pp. 338-340; April, 1916.

SAFFORD, F. H. An irrational transformation of the Weierstrass 8 -function curves. Read April 24, 1915. Archiv der Mathematik und Physik, ser. 3, vol. 24, No. 4, pp. 342-344; March, 1916.

SHAw, J. B. On parastrophic algebras. Read (Chicago) Dec. 29, 1914. Transactions of the American Mathematical Society, vol. 16, No. 3, pp. 361-370; July, 1915.

Stsam, C. H. On rational sextic surfaces having a nodal curve of order 9. Read (Chicago) April 2, 1915. American Journal of Mathematics, vol. 37 , No. 4, pp. 445-456; Oct., 1915.

- On surfaces doubly generated by conics. Read Dec. 31, 1915. Quarterly Journal of Pure and Applied Mathematics, vol. 47, No. 1, pp. 55-72; March, 1916.

On a configuration on certain surfaces. Read (Chicago) April 21, 1916. Bulletin of the American Mathematical Society, vol. 22, No. 8, pp. 381-383; May, 1916.

Steimley, L. L. On the solutions of linear non-homogeneous partial differential equations. Read (Chicago) Dec. 28, 1914. American Journal of Mathematics, vol. 37, No. 4, pp. 359-366; Oct., 1915.

SToufFer, E. B. On seminvariants of linear homogeneous differential equations. Read (Chicago) April 3, 1915. Proceedings of the London Mathematical Society, ser. 2, vol. 15, No. 3, pp. 217-226; May, 1916.

TAPPAN, A. H. Plane sextic curves invariant under birational transformations. Read Dec. 30, 1913. American Journal of Mathematics, vol. 37, No. 3, pp. 309-336; July, 1915.

Vallée Poussin, C. J. De la. Sur l'intégrale de Lebesgue. Read April 24, 1915 and Aug. 3, 1915. Transactions of the American Mathematical Society, vol. 16, No. 4, pp. 435-501; Oct., 1915.

VANDIVER, H. S. An aspect of the linear congruence with applications to the theory of Fermat's quotient. Read Aug. 4, 1915. Bulletin of the American Mathematical Society, vol. 22, No.2, pp. 61-67; Nov., 1915. 
Van Vleck, E. B. and H'Doubler, F. T. A study of certain functional equations for the $\vartheta$-functions. Read Sept. 9, 1913. Transactions of the American Mathematical Society, vol. 17, No. 1, pp. 9-49; Jan., 1916.

WaHLin, G. E. A new development of the theory of algebraic numbers. Read (Chicago) April 2, 1915. Transactions of the American Mathematical Society, vol. 16, No. 4, pp. 502-508; Oct., 1915.

WEDDERBURN, J. H. M. On matrices whose coefficients are functions of a single variable. Read Sept. 9, 1914. Transactions of the American Mathematical Society, vol. 16, No. 3, pp. 328-332; July, 1915.

WhIte, H. S. Seven points on a twisted cubic curve. Read Aug. 3, 1915. Proceedings of the National Academy of Sciences, vol. 1, No. 8, pp. 464-466; Aug., 1915.

Poncelet polygons. Read Dec. 30, 1915. Science, new ser., vol. 43, No. 1101, pp. 149-158; Feb. 4, 1916. See Cummings, L. D.

Wilczynski, E. J. The general theory of congruences. Read (Chicago) Dec. 28, 1914. Transactions of the American Mathematical Society, vol. 16, No. 3, pp. 311-327; July, 1915.

- Some remarks on the historical development and the future prospects of the differential geometry of plane curves. Read (Chicago) April 11, 1914 and Dec. 30, 1915. Bulletin of the American Mathematical Society, vol. 22, No. 7, pp. 317-329; April, 1916.

- Interpretation of the simplest integral invariant of projective geometry. Read Jan. 1, 1916. Proceedings of the National Academy of Sciences, vol. 2, No. 4, pp. 248-252; April, 1916.

WILDER, C. E. On the degree of approximation to discontinuous functions by trigonometric sums. Read Feb. 22, 1913 and April 25, 1914. Rendiconti del Circolo Matematico di Palermo, vol. 39, No. 3, pp. 345361; May-June, 1915.

Williams, K. P. A theorem concerning real functions. Read (Southwestern Section) Nov. 27, 1915. Annals of Mathematics, ser. 2, vol. 17, No. 2, pp. 72-73; Dec., 1915.

- Concerning Hill's derivation of the Lagrange equations of motion. Read (Chicago) April 22, 1916. Bulletin of the American Mathematical Society, vol. 22, No. 9, pp. 455-457; June, 1916.

WILson, E. B. Linear momentum, kinetic energy, and angular momentum. Read April 24, 1915. American Mathematical Monthly, vol. 22, No. 6, pp. 187-193; June, 1915.

- Changing surface to volume integrals. Read Feb. 26, 1916. Bulletin of the American Mathematical Society, vol. 22, No. 7, pp. 336-337; April, 1916.

- Critical speeds for flat disks in a normal wind. Prefatory note on normal flow past a circular disk. Read Feb. 26, 1916. Smithsonian Miscellaneous Collections, vol. 62, No. 4, pp. 77-83; Jan. 15, 1916.

Wilson, E. B. and Moore, C. L. E. A general theory of surfaces. Read Dec. $27,1915 . \quad$ Proceedings of the National Academy of Sciences, vol. 2, No. 5, pp. 273-278; May, 1916. 
Wilson, W. A. On separated sets. Read April 29, 1916. Bulletin of the American Mathematical Society, vol. 22, No. 8, pp. 384-386; May, 1916.

Wingen, R. M. Self-projective rational sextics. Read Sept. 9, 1913. American Journal of Mathematics, vol. 38, No. 1, pp. 45-56; Jan., 1916. 